Rachid, S., Huo, L., Herrmann, J., Stadler, M., Köpcke, B., Bitzer, J., Müller, R.

Mining the Cinnabaramide Biosynthetic Pathway to Generate Novel Proteasome Inhibitors

(2011) ChemBioChem, 12 (6), pp. 922-931 


\title{
Mining the Cinnabaramide Biosynthetic Pathway to Generate Novel Proteasome Inhibitors
}

\author{
Shwan Rachid, ${ }^{[a, b, c]}$ Liujie Huo, ${ }^{[a, b]}$ Jennifer Herrmann, ${ }^{[a, b]}$ Marc Stadler, ${ }^{[d]}$ Bärbel Köpcke, ${ }^{[d]}$ \\ Jens Bitzer, ${ }^{[\mathrm{d}]}$ and Rolf Müller ${ }^{*[a, b]}$
}

\begin{abstract}
The cinnabaramides and salinosporamides are mixed PKS/ NRPS natural products isolated from a terrestrial streptomycete and a marine actinomycete, respectively. They interfere with the proteasome and thus potentially inhibit the growth of cancer cells. The compounds exhibit a $\gamma$-lactam- $\beta$-lactone bicyclic ring structure attached to a cyclohexenyl unit and a PKS side chain. As a first step towards improving anticancer activity and permitting genetic approaches to novel analogues, we have cloned and characterized the cinnabaramide biosynthetic genes from Streptomyces sp. JS360. In addition to the expected PKS and NRPS genes, the cluster encodes functionalities for the assembly of the hexyl side chain precursor. The corre-
\end{abstract}

\section{Introduction}

Natural products continue to fulfill their enormous potential in the development of future drugs and to serve as compounds of interest both in their natural forms and as semisynthetic or synthetic derivatives. Drugs derived from natural products are used for therapy for more than $87 \%$ of human diseases, and include anticancer, antifungal, antibacterial, anticoagulant, antiparasitic, and immunosuppressant agents, amongst others. ${ }^{[1,2]}$

An important role in drug discovery in the past century has been played by microorganisms, in particular bacteria of the genus Streptomyces, which produce secondary metabolites in unprecedented chemical diversity, exhibiting a remarkable array of biological activity. Many of them are clinically valuable agents. ${ }^{[3,4]}$ The metabolites isolated from this genus are mostly end products of the enzymes of two major types of biosynthetic pathways: the non-ribosomal peptide synthetases (NRPSs) and the polyketide synthases (PKSs). ${ }^{[4]}$ NRPSs and PKSs are made up of so-called modules, which are sets of distinct active sites for catalyzing each condensation and chain-elongation step. ${ }^{[5,6]}$ Each module in an NRPS or a PKS consists of certain obligatory or core domains for addition of each peptide or ketide unit and a variable number of optional domains responsible for modification of the peptide/ketide backbone. ${ }^{[7,8]}$

The terrestrial Streptomyces sp. JS360 is known to produce cinnabaramides $A-G$, each exhibiting a $\gamma$-lactam- $\beta$-lactone bicyclic ring structure attached to a cyclohexenyl unit, together with a hexyl side chain. ${ }^{[9]}$ With the exception of the hexyl side chain, significant structure similarity was found between these compounds and the salinosporamides (Scheme 1), a class of PKS/NRPS antitumor metabolites isolated from the marine actinomycetes Salinispora tropica CNB-440 ${ }^{[10-12]}$ and Salinospora sponding enzymes exhibit relaxed substrate specificities towards a number of synthesized precursors, enabling production of novel chlorinated cinnabaramides. These were isolated and analyzed for activity, revealing that derivatives bearing a chlorine atom in the PKS side chain show higher inhibitory potentials towards the proteasome's proteolytic subunits (especially the trypsin and chymotrypsin units) and higher cytotoxicities towards human tumor cell lines than the parent cinnabaramide $A$. Although their activities towards the proteasome were weaker than that of salinosporamide $A$, the cinnabaramides were found to inhibit the growth of various fungi with greater potency.
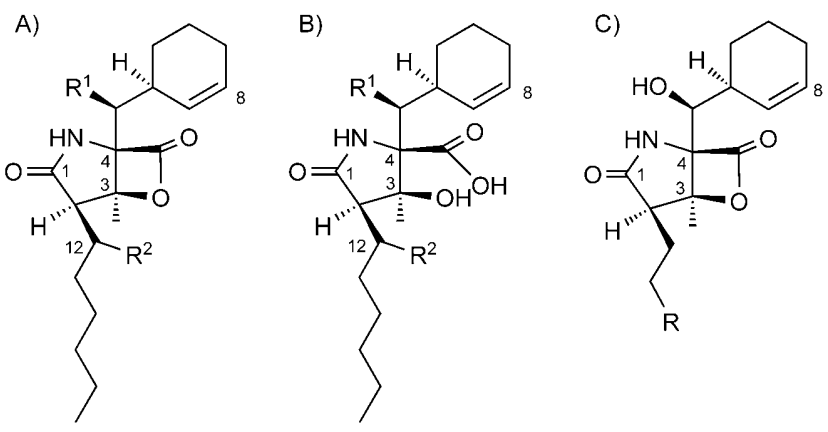

Scheme 1. Structures of cinnabaramides and salinosporamides. A) Cinnabaramide $A\left(R^{1}=O H, R^{2}=H\right)$, cinnabaramide $B\left(R^{1}=R^{2}=O H\right)$, and cinnabaramide $C\left(R^{1}=R^{2}=H\right)$. B) Cinnabaramide $D\left(R^{1}=R^{2}=O H\right)$ and cinnabaramide $E$ $\left(R^{1}=\mathrm{OH}, \mathrm{R}^{2}=\mathrm{H}\right)$. C) Salinosporamide $A(R=C l)$ and salinosporamide $B$ $(\mathrm{R}=\mathrm{H})$.

[a] Dr. S. Rachid, L. Huo, J. Herrmann, Prof. Dr. R. Müller Department of Microbial Natural Products (MINS) Helmholtz Institute for Pharmaceutical Research Saarland (HIPS) Helmholtz Centre for Infection Research (HZI), Saarland University Campus C2.3, 66123 Saarbrücken (Germany)

[b] Dr. S. Rachid, L. Huo, J. Herrmann, Prof. Dr. R. Müller Department of Pharmaceutical Biotechnology, Saarland University Campus C2.3, P.O. Box 1511 50, 66041 Saarbrücken (Germany) Fax: (+49)6181-302-70202

E-mail:rom@mx.uni-saarland.de

[c] Dr. S. Rachid Current address: College of Pharmacy University of Sulaimani, Sulaiamni (Iraq)

[d] Dr. M. Stadler, Dr. B. Köpcke, Dr. J. Bitzer InterMed Discovery $\mathrm{GmbH}$ Otto-Hahn-Strasse 15, 44227 Dortmund (Germany)

Supporting information for this article is available on the WWW under http://dx.doi.org/10.1002/cbic.201100024. 
pacifica CNT-113. ${ }^{[13]}$ Both cinnabaramides and salinosporamides exhibit potent cancer cell cytotoxicities and exert their effects through binding to the $20 \mathrm{~S}$ proteasome core particle, thereby inducing cell cycle arrest and programmed cell death (apoptosis). ${ }^{[9,14-16]}$ The key to the superior activity of salinosporamide $A$ versus the cinnabaramides is assumed to be the presence of the chlorine atom attached to the side chain, which is required for the drug's irreversible binding to its biological target and is thus a major reason for the compound's effectiveness against cancer. ${ }^{[17]}$

We anticipated that the factor behind the varying side chains in the two compound classes should be a biosynthetic enzyme responsible for forming a hypothetical and unusual hexylmalonyl-CoA extender unit. By mining the substrate tolerance of this enzyme towards chlorinated and unsaturated fatty acid-CoA esters and using feeding experiments we succeeded in generating chlorinated analogues of the cinnabaramides and in analyzing their bioactivities.

\section{Results and Discussion}

To achieve our goal, we first set out to identify the biosynthetic machinery of cinnabaramides. Because the overall structure of cinnabaramides is suggestive of a biosynthetic origin based upon PKS and NRPS machinery and because the gene cluster for salinosporamides (sal) is known, ${ }^{[18]}$ a cosmid library was constructed from the genome of strain JS360 and screened for the corresponding gene cluster in an approach based on hybridization with degenerated PKS and NRPS (as described in the Experimental Section).

Within the identified cin gene cluster, at least six likely structural genes were designated $\operatorname{cin} A-F$, encoding two PKS modules and a split NRPS module distributed over the first two genes ( $\operatorname{cin} A$ and $\operatorname{cin} B$ ), followed by a standalone ketosynthase, a P450 monooxygenase, a standalone thioesterase, and a homologue of crotonyl-CoA carboxylase/reductase ( $\mathrm{Ccr}$; cinF) (Table 1 and Scheme 2A), which can be assigned to roles in cinnabaramide core biosynthesis. Further genes are encoded upstream and downstream of the gene cluster and would be expected to be involved in production of the biosynthesis precursors ( $\operatorname{cin} Q$ and $\operatorname{cin} P$ ), post-assembly-line modification of the compound ( $\operatorname{cin} L)$, bacterial resistance against the compound (cinJ), and regulation of the gene cluster ( $\operatorname{cinRI}$ and cinRII) (Table 1). It is likely that the biosynthesis of cinnabaramides is carried out in a thiotemplated fashion, in which intermediates are covalently tethered to phosphopantetheinyl arms of carrier proteins (Scheme $2 \mathrm{~B}$ ). ${ }^{[19]}$ CinA consists of an atypically arranged starter module and one extension module (ACP-KS-AT ${ }_{1}-\mathrm{AT}_{2}-$ $A C P-C)$. We assume that the initiation step is selection and loading to the ACP of the starter unit acetyl-CoA by the first AT domain. According to the chemical structure of the compound, the second PKS module catalyzes chain elongation of acetyl-S-ACP with the unusual extender unit hexylmalonyl-S$A C P$ and results in the incorporation of the hexyl side chain. A bioinformatics-based approach to identify the substrate specificity of CinA-ATs, in comparison with the ATs of other biosynthetic pathways, ${ }^{[20]}$ indeed showed conserved residues in the
ATs implicated in binding of dicarboxylated extender units (Table 1). Interestingly, the substrate specificity of AT1 is predicted to be for acetyl-CoA and the conserved residues are almost identical to the salinosporamide domain. AT2, however, is different from AT2 in its salinosporamide counterpart. Unexpectedly, it also differs from the hexylmalonyl-CoA-specific TugC-AT3 (Table S1B in the Supporting Information) involved in the biosynthesis of thuggacins-macrolide antibiotics bearing hexyl side chains-from the myxobacterium Sorangium cellulosum So ce895, which are also produced through a NRPS/PKS biosynthetic pathway. ${ }^{[21-23]}$

The C-terminal domains of CinA and CinB form the terminal NRPS module of the assembly line, and the highly homologous domain set in the salinosporamide gene cluster is known to activate the nonproteinogenic amino acid $\beta$-hydroxy- $2^{\prime}$-cyclohexenylalanine. ${ }^{[12,24]}$ Because of the structural similarity of the two compounds, and because the deduced substrate specificity code of the CinB A domain (DLMNVGGV; determined as described previously ${ }^{[25,26]}$ ) showed a significant degree of similarity to that of the SalB A domain (DLLSNGGV), we propose elongation of the cinnabaramide intermediate by extension with $\beta$-hydroxy-2'-cyclohexenylalanine (Scheme $2 \mathrm{~B}$ ). The resulting PCP-tethered cinnabaramide intermediate is then thought to undergo an intramolecular condensation promoted by the ketosynthase (CinC) to generate the $\gamma$-lactam ring, which provides the CinB-bound alcohol substrate that gives rise to the offloaded $\beta$-lactone product. It is assumed that the standalone CinE catalyzes release and cyclization of the intermediate to generate the $\beta$-lactone ring of the compound. The gene cluster harbors genes ( $\operatorname{cin} Q$ and $\operatorname{cin} P$ ) that encode putative Lamino acid aminotransferases and a prephenate dehydratase, respectively (Table 1 ). Similar enzymes have also been described in the salinosporamide biosynthesis pathway-it was suggested that these were involved in cyclohexenyl-alanine building block formation-and inactivation of a prephenate dehydratase homologue gene $(s a \mid X)$ in the sal cluster led to the elimination of all natural salinosporamides. ${ }^{[12,27]}$

It has been reported that the salinosporamide biosynthetic enzymes responsible for the activation and incorporation of the native sal-specific amino acid exhibit relaxed substrate specificities towards a number of aliphatic amino acids. ${ }^{[2]}$ In that work, Moore and co-workers used a comprehensive approach that combined chemical synthesis with metabolic engineering to generate a series of salinosporamide analogues with altered bioactivities against human cancer cell lines. Two salinosporamide derivatives with saturated cyclohexane or cyclopentane rings were prepared by mutasynthesis, through administration of derivatives and branched-chain amino acids to a culture of the $S$. tropica salX mutant strain. ${ }^{[29]}$

To establish the function of cinQ in the salinosporamide gene cluster we inactivated the gene by insertion of an inactivation plasmid (pCN2) into the Streptomyces JS360 genome, leading to complete elimination of cinnabaramide biosynthesis in the mutant. When we attempted to restore product formation by feeding cyclopentyl-DL-alanine to the culture, new compounds exhibiting the expected masses were indeed detected. NMR spectroscopic examination of the purified cinna- 


\begin{tabular}{|c|c|c|c|c|c|c|}
\hline Gene & Protein & $\begin{array}{l}\text { Residues } \\
\text { [aa] }\end{array}$ & Proposed function & Sequence identity/similarity to $[\%]^{[a]}$ & $\begin{array}{l}\text { Accession } \\
\text { number }\end{array}$ & $\begin{array}{l}\text { Sequence identity/similarity to } \\
\text { Salinispora tropica CNB- } 440^{[18]}[\%]^{[b]}\end{array}$ \\
\hline $\operatorname{cin} A$ & Cin $A$ & 2040 & $\begin{array}{l}\mathrm{PKS} / \mathrm{NRPS}\left(\mathrm{ACP} \mathrm{P}_{1}-\mathrm{KS}-\mathrm{AT}_{1}-\right. \\
\left.\mathrm{AT}_{2}-\mathrm{ACP}_{2}-\mathrm{C}\right)\end{array}$ & $\begin{array}{l}\text { SalA, PKS/NRPS, Salinispora tropica CNB-440, } \\
62 / 72\end{array}$ & ABP73645 & SalA, PKS/NRPS, 60/71 \\
\hline $\operatorname{cin} B$ & CinB & 585 & NRPS $(A-A C P)$ & SalB, NRPS, Salinispora tropica CNB-440, 66/76 & ABP73646 & SalB, NRPS, 61/71 \\
\hline $\operatorname{cin} C$ & CinC & 596 & ketosynthase & $\begin{array}{l}\text { SalC, erythronolide synthase, Salinispora tropica } \\
\text { CNB-440, } 66 / 79\end{array}$ & $\begin{array}{l}Y_{-} \\
001157874\end{array}$ & SalC, erythronolide synthase, $63 / 76$ \\
\hline $\operatorname{cin} D$ & CinD & 414 & cytochrome P450 & $\begin{array}{l}\text { SalD, cytochrome P450 hydroxylase, Salinispora } \\
\text { tropica CNB-440, } 76 / 88\end{array}$ & ABP73648 & $\begin{array}{l}\text { SalD, cytochrome P450 hydroxylase, } \\
72 / 84\end{array}$ \\
\hline $\operatorname{cin} E$ & CinE & 277 & thioesterase & $\begin{array}{l}\text { SalF, thioesterase, Salinispora tropica CNB- } 440 \text {, } \\
70 / 80\end{array}$ & ABP73650 & SalF, thioesterase, $64 / 74$ \\
\hline $\operatorname{cin} F$ & CinF & 448 & $\begin{array}{l}\text { octenoyl-CoA reductase/ } \\
\text { carboxylase }\end{array}$ & $\begin{array}{l}\text { crotonyl-CoA reductase, Streptomyces hygro- } \\
\text { scopicus, 93/96 }\end{array}$ & AAR32675 & $\begin{array}{l}\text { SalG, 4-chlorocrotonyl-CoA reductase/ } \\
\text { carboxylase, } 67 / 81\end{array}$ \\
\hline $\operatorname{cinRl}$ & CinRI & 333 & $\begin{array}{l}\text { regulatory protein, LysR } \\
\text { family }\end{array}$ & $\begin{array}{l}\text { LysR family transcriptional regulator, Strepto- } \\
\text { myces griseus subsp. griseus NBRC } 13350,48 / 60\end{array}$ & $\begin{array}{l}Y_{-} \\
001828298\end{array}$ & - \\
\hline $\mathrm{cinH}$ & $\mathrm{CinH}$ & 733 & NRPS & NRPS, Streptomyces avermitilis MA-46801, 50/60 & NP_822023 & - \\
\hline cinl & Cinl & 506 & acyl-CoA dehydrogenase & $\begin{array}{l}\text { acyl-CoA dehydrogenase, Streptomyces bing- } \\
\text { chenggensis BCW-1, 40/55 }\end{array}$ & ADI05331 & - \\
\hline cinJ & CinJ & 281 & $\begin{array}{l}20 S \text { proteasome } \beta \text {-subu- } \\
\text { nit }\end{array}$ & $\begin{array}{l}20 \mathrm{~S} \text { proteasome } \beta \text {-subunit, Streptomyces aver- } \\
\text { mitilis MA- } 4680,74 / 88\end{array}$ & NP_823988 & Sall, proteasome $\beta$-subunit, $40 / 60$ \\
\hline $\operatorname{cink}$ & CinK & 66 & ferredoxin-2 & ferredoxin-2, Streptomyces diastaticus, 55/73 & P18325 & - \\
\hline $\operatorname{cin} L$ & CinL & 402 & cytochrome P450 & $\begin{array}{l}\text { putative cytochrome } \mathrm{P} 450 \text {, Streptosporangium } \\
\text { roseum DSM 43021, } 49 / 63\end{array}$ & $\begin{array}{l}Y_{-} \\
003340485\end{array}$ & - \\
\hline $\operatorname{cin} M$ & CinM & 280 & $\begin{array}{l}\text { phenazine biosynthesis } \\
\text { (oxidizing protein) }\end{array}$ & $\begin{array}{l}\text { PhzF family phenazine biosynthesis protein, } \\
\text { Salinispora tropica CNB- } 440,69 / 80\end{array}$ & $\begin{array}{l}\text { YP_- } \\
001157895\end{array}$ & $\begin{array}{l}\text { PhzF family phenazine biosynthesis } \\
\text { protein, } 69 / 80\end{array}$ \\
\hline $\operatorname{cin} N$ & $\operatorname{CinN}$ & 95 & hypothetical protein & $\begin{array}{l}\text { hypothetical protein Strop_1042, } \\
\text { Salinispora tropica CNB-440, 71/78 }\end{array}$ & $\begin{array}{l}Y P_{-} \\
001157894\end{array}$ & $\begin{array}{l}\text { hypothetical protein strop_1042, } \\
71 / 78\end{array}$ \\
\hline $\operatorname{cinO}$ & $\mathrm{CinO}$ & 329 & ornithine cyclodeaminase & $\begin{array}{l}\text { ornithine cyclodeaminase, Salinispora tropica } \\
\text { CNB-440, } 71 / 83\end{array}$ & $\begin{array}{l}Y_{-} \\
001157893\end{array}$ & ornithine cyclodeaminase, $71 / 83$ \\
\hline $\operatorname{cin} P$ & CinP & 205 & prephenate dehydratase & $\begin{array}{l}\text { BacA, prephenate dehydratase, Bacillus amylo- } \\
\text { liquefaciens, } 36 / 58\end{array}$ & Q8KWT1 & - \\
\hline $\operatorname{cin} Q$ & CinQ & 331 & $\begin{array}{l}\text { L-amino acid aminotrans- } \\
\text { ferase }\end{array}$ & $\begin{array}{l}\text { SalW, L-amino acid transferase, Salinispora } \\
\text { tropica CNB-440, 70/80 }\end{array}$ & $\begin{array}{l}Y P_{-} \\
001157891\end{array}$ & $\begin{array}{l}\text { SalW, L-amino acid transferase, } \\
36 / 79\end{array}$ \\
\hline $\operatorname{cin} R$ & CinR & 447 & phenyl-acetate-CoA ligase & $\begin{array}{l}\text { hypothetical protein Strop_1038, Salinispora } \\
\text { tropica CNB-440, 70/81 }\end{array}$ & $\begin{array}{l}Y P_{-} \\
001157890\end{array}$ & $\begin{array}{l}\text { hypothetical protein Strop_1038, } \\
70 / 81\end{array}$ \\
\hline $\operatorname{cins}$ & Cins & 352 & $\begin{array}{l}\text { 3-oxoacyl-(acyl-carrier } \\
\text { protein) synthase III }\end{array}$ & $\begin{array}{l}\text { 3-oxoacyl-(acyl-carrier protein), Streptomyces } \\
\text { hygroscopicus, 90/93 }\end{array}$ & AAR32677 & - \\
\hline $\operatorname{cin} T$ & CinT & 591 & acyl-CoA ligase & $\begin{array}{l}\text { acyl-CoA ligase, Streptomyces hygroscopicus, } \\
87 / 92\end{array}$ & AAR32676 & - \\
\hline $\operatorname{cin} R \|$ & CinRII & 323 & $\begin{array}{l}\text { regulatory protein, LuxR } \\
\text { family }\end{array}$ & $\begin{array}{l}\text { LuxR transcriptional regulator, Streptomyces } \\
\text { flavogriseus, } 49 / 65\end{array}$ & $\begin{array}{l}Z P_{-} \\
05802671\end{array}$ & - \\
\hline
\end{tabular}

[a] Protein Blast (Database: nonredundant protein sequences (nr)). [b] Geneious alignment (cost matrix: BLOSUM62, Gap open penalty: 11, Gap extension penalty: 3)

baramide $A$ analogue $\left(\mathrm{C}_{18} \mathrm{H}_{29} \mathrm{NO}_{4}: \mathrm{m} / \mathrm{z}: 324.2[\mathrm{M+H}]^{+}\right)$revealed that the derivatives made by mutasynthesis were novel cinnabaramides each carrying a cyclopentyl instead of cyclohexenyl ring (Table S1 and Figures S1 and S4).

Because the $\operatorname{cin} D$ gene encodes a putative cytochrome P450 enzyme we suggest that this enzyme is involved in postassembly-line hydroxylation of the compound to produce the $\beta$-hydroxycyclohex-2-enylalanine residue in cinnabaramides $A$, $B, D$, and $E$.

Administration of deuterated cyclohexenyl-serine to the culture of Streptomyces JS360 showed no incorporation of the compound into the cinnabaramides, which indicates that the cinnabaramide biosynthesis enzymes exhibit no tolerance toward alteration in the $\beta$-position of the amino acid precursor. Interestingly, the salinosporamide megasynthetase was shown to tolerate both secondary and tertiary carbons in the $\gamma$-posi- tion of the amino acid precursor, but substitution in the $\beta$ position was also not accepted. ${ }^{[12]}$ The authors suggested that the latter substitution might directly affect the function of the cytochrome P450 enzyme (SaID) in the pathway.

A second copy of a cytochrome P450 is encoded by cinL in the upstream region of the cin gene cluster (Table 1). Because cinL shows no counterpart in the salinosporamide pathway we suggest that the corresponding protein plays a role in hydroxylation of cinnabaramides $B$ and $D$ at $C 12$, whereas $\operatorname{cin} D$ is responsible for production of the $\mathrm{C} 5$ hydroxy functionality in $A, B$, and D (Scheme 2B).

After identifying the biosynthetic pathway of cinnabaramides, we predicted that the hexyl side chain of the compound might originate from a hexylmalonyl-CoA extender unit (Schemes 2B and 3A). This assumption was based on previous observations in other biosynthetic pathways involving unusual 
A)

$\operatorname{cin}$

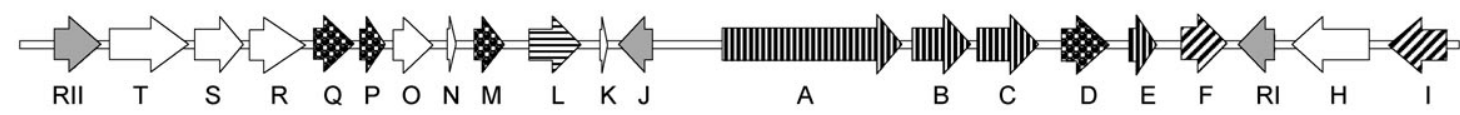

sal

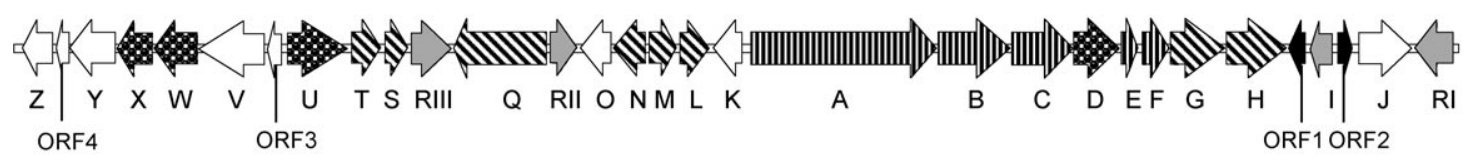

B)

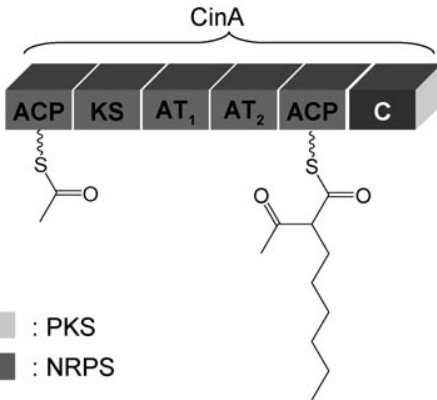

ACP: acyl carrier protein

$\mathrm{KS}$ : ketosynthase domain

AT: acyl transferase domain

C: condensation domain

A: adenylation domain

PCP: peptidyl carrier protein

TE: thioesterase domain
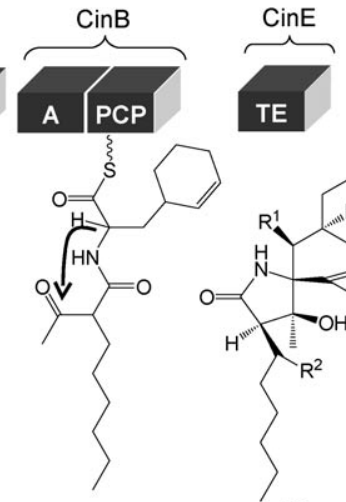

Scheme 2. A) Organization of the cin biosynthetic gene cluster from Streptomyces sp. JS360 and of the sal biosynthetic gene cluster from Salinospora tropica. Genes of similar function in both salinosporamide and cinnabaramide biosynthesis: genes involved in construction of the core structure $\gamma$-lactam- $\beta$-lactone bi-

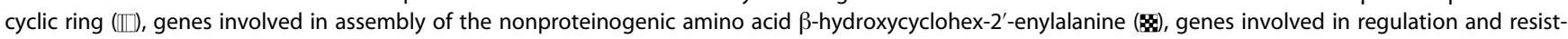
ance $(\square)$. Specific genes existing only in the cinnabaramide biosynthesis cluster: genes involved in the 2-carboxyl-CoA pathway ( hydroxylation of C12 in cinnabaramides B and D (巨). Specific genes existing only in the salinosporamide biosynthesis cluster: partial transposases ( $\square$ ), genes involved in the chloroethylmalonyl-CoA pathway ( $\mathbb{\$}$. Genes of unknown function in biosynthesis of cinnabaramides and salinosparamides ( $\square$ ). B) Proposed PKS/NRPS biosynthesis pathway for production of cinnbaramides.

extender units of polyketides and predominantly the work relating to the ethylmalonyl-CoA pathway in Rhodobacter sphaeroides. In this pathway, reductive carboxylation of $(E)$-crotonylCoA by a crotonyl-CoA carboxylase/reductase $(\mathrm{Ccr})$ enzyme ${ }^{[30]}$ with use of the purified enzyme in vitro has been described. Similar biochemical steps have also been reported to be involved in the production of the PKS extender units ethylmalonyl-CoA and chloroethylmalonyl-CoA in the salinosporamide biosynthesis pathway. ${ }^{[31]}$ Another example has been reported in the biosynthesis of the NRPS/PKS macrolide thuggacin, isolated from Sorangium cellulosum So ce895, in which it was proposed that the hexyl side chain of the compound originates from extension by the unusual PKS extender hexylmalonyl$\mathrm{CoA}$, which is thought to be generated from octenyl-CoA by the $\mathrm{Ccr}$ homologue $\operatorname{TgaD}^{[21]}$ In the cinnabaramide gene cluster we found a gene (cinF) encoding for a protein showing $90 \%$ sequence identity (at the protein level) to a putative Ccr from Streptomyces hygroscopicus (Accession No. AAR32675). However, sequence identity to TgaD is very low. We inactivated $\operatorname{cinF}$ by insertion of the inactivation plasmid pCN1 into the genome of Streptomyces sp. JS360 through homologous recombination, resulting in a mutant incapable of producing cinnabaramides. We thus hypothesize that CinF catalyzes the reductive carboxy- lation of octenoyl-CoA or -ACP, leading to 2-carboxyoctanoylCoA or 2-carboxyoctanoyl-ACP, respectively (Schemes $3 \mathrm{~B}$ and 4). Notably, the octenoyl-CoA and octenoyl-ACP precursors to the proposed building blocks are intermediates furnished either from the fatty acid degradation or the fatty acid biosynthesis pathways.

We speculated that the corresponding free acids obtained from administration to the growth media might be activated in the cell and thus enable mutasynthesis of analogues, and consequently next turned our attention towards the production of chlorinated cinnabaramides. A precursor-directed biosynthesis strategy was applied by feeding of the bacterial culture with chlorinated precursors. Accordingly, (E)-6-chlorooct-2enoic acid, (E)-8-chlorooct-2-enoic acid, and their corresponding $\mathrm{N}$-acetylcysteamine (NAC) thioesters were chemically synthesized (Figure S1) and added to the culture of the bacteria (Scheme 3C). Organic extracts of the culture supernatants were analyzed by HPLC-MS, which unambiguously showed incorporation of these precursors into cinnabaramide $A$ (and into other cinnabaramide derivatives; data not shown) bearing a chlorine atom (Figure 1). After scale-up of the precursor feeding experiment, these compounds were also isolated to purity by preparative HPLC (details provided in the Supporting Infor- 
A)
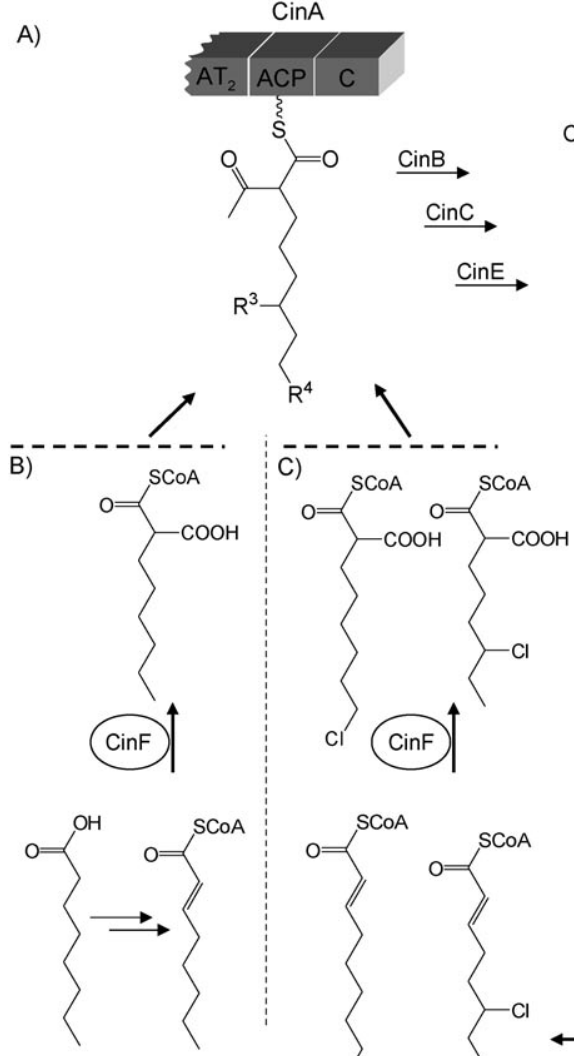

$\mathrm{O}=$

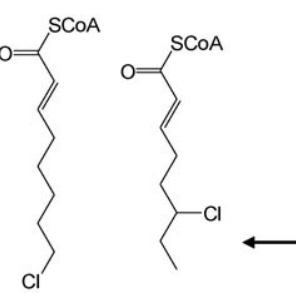

Culture feeding with: (E)-6-chlorooct-2-enoic acid (E)-8-chlorooct-2-enoic acid

Scheme 3. A) Biosynthetic pathway producing the cinnabaramide hexyl side chain. B) Putative role of CinF (carboxylase/reductase) in the pathway. C) Culture feeding with 6- or 8-chlorooct-2-enoic acid as an analogue precursor for the biosynthesis of chlorinated cinnabaramides.

mation) in order to allow their unambiguous structure elucidation.

1D and 2D NMR spectroscopy for structure elucidation (Table S4 and Figure S4), combined both with LC-MS data and with high-resolution ESI-MS (for comparison with cinnabaramide A; Scheme 4 and Table S2), identified the structures as novel chlorinated cinnabaramides with chlorine atoms at $\mathrm{C} 15$ or C17. From these results, we reason that the cinnabaramide PKS extender module is able to accept chlorinated substrates and to incorporate them into the assembly line. No production

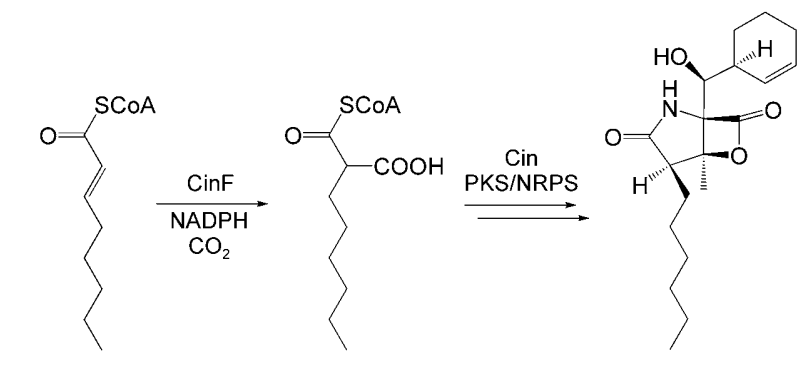

oct-2-enoyl-CoA 2-carboxy-octanoyl-CoA

cinnabaramide A

Scheme 4. The presumed mechanism for production of the PKS extender unit hexylmalonyl-CoA, which is required for the formation of the hexyl side chain in cinnabaramides.

of chlorinated cinnabaramides was found when the bacterial culture was supplemented with $(E)$-4-chlorooct-2-enoic acid, so we postulate that the presence of the chlorine atom at this position might influence the substrate in such a way that it cannot be properly positioned in the CinA-AT 2 active site. Alternatively, Cinf might not accept this substrate for reductive carboxylation.

Novel cinnabaramide A derivatives were isolated and screened against the human $20 \mathrm{~S}$ proteasome (more precisely, against the proteolytic subunits with chymotrypsin-like (CT-L), trypsin-like (T-L), and caspase-like (C-L) activities) in vitro. As shown in Table 2 salinosporamide $A$ has a higher inhibitory potential towards all three proteolytic subunits than the tested cinnabaramides. The $\mathrm{IC}_{50}$ values determined for the CT-L activity were all in the low nanomolar range, as reported previously, ${ }^{[9,32-34]}$ although the chloro derivatives are more potent than the parent compound. With regard to inhibition at the T-L active site, 15chlorocinnabaramide $\mathrm{A}$ showed the highest activity amongst the derivatives. The additional chlorine might serve as a leaving group and in this way enhance cinnabaramide's potency for inhibiting the $\beta 2$ proteolytic subunit, as described earlier for inhibition at the CT-L site by salinosporamide $A .{ }^{[17]}$ In the case of $C-L$ activity, cinnabaramide $A$ and its analogues exhibited $I C_{50}$ values in the high nanomolar range.

As shown in Table 3, the cytotoxic activities of the novel 15-chloro derivative were superior to those of cinnabaramide $A$, whereas the 17-chloro derivative showed enhanced bioactivity only towards human myeloma RPMI-8226 cells. These findings are consistent with the results from the proteasome inhibition experiments. In general, the cytotoxic effects are still significantly weaker than those of salinosporamide $A$.

In addition to proteasome inhibition, the cinnabaramides showed strong antifungal activity. Although Botrytis cinerea was found to be insensitive towards the compounds, both Mucor plumbeus and Pyricularia oryzae were affected by low concentrations of the cinnabaramides, as well as by salinosporamide $A$ (as shown in Table S3). Interestingly, the last compound showed the weakest antifungal activity, despite being much more potent than the cinnabaramides against the concurrently tested cancer cell lines. The chlorinated cinnabaramides and the cyclopentyl analogue of cinnabaramide A, however, were slightly less active than their parent compound.

\section{Experimental Section}

General microbiological and molecular biology methods: The cinnabaramide producer JS360 was grown in Q6 medium, which led to maximal production rate as described previously. ${ }^{[9]}$ Cells of Escherichia coli were grown in Luria-Bertani (LB) medium at $37^{\circ} \mathrm{C}$. dNTPs, restriction enzymes, T4 DNA ligase, isopropyl $\beta$-D-thiogalactopyranoside (IPTG), and X-gal were purchased from Fermentas. Ammonium persulfate and gel electrophoresis materials were ob- 

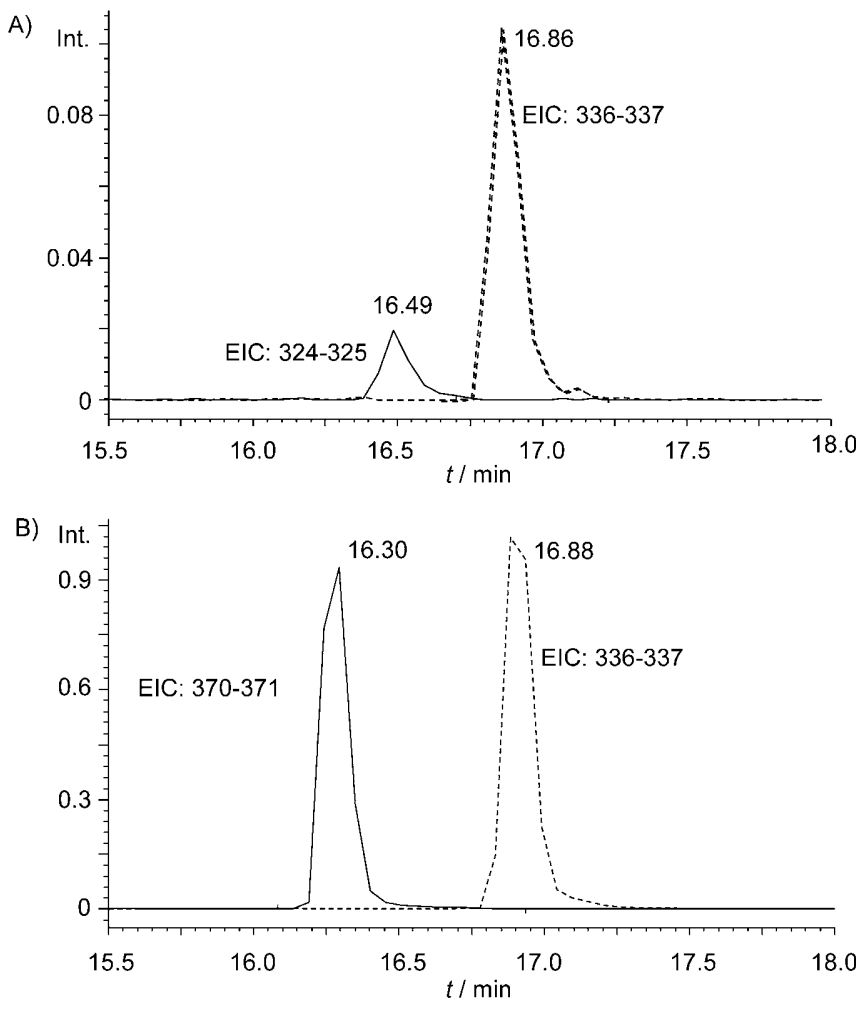

Figure 1. HPLC-MS analyses with extracted ion chromatograms (EICs) for $m / z$ values of cinnabaramide $A\left(t_{R}=16.9 \mathrm{~min}\right.$; dashed line) and new cinnabaramide A derivatives. A) Feeding of strain JS360 with cyclopentyl-alanine resulting in the production of cyclopentyl-alanine cinnabaramide $A\left(t_{R}=\right.$ 16.49 min). B) Feeding of JS360 with 6- or 8-chlorooct-2-enoic acid or their SNAC derivatives, resulting in the production of cinnabaramide $A$ analogues chlorinated at $\mathrm{C} 15$ or $\mathrm{C} 17\left(t_{\mathrm{R}}=16.30 \mathrm{~min}\right)$, respectively. The two chlorinated compounds had identical retention times on the applied system and showed similar levels of production.

Table 2. Inhibition of the $\beta 1, \beta 2$, and $\beta 5$ proteolytic subunits of human $20 \mathrm{~S}$ proteasome by salinosporamide $\mathrm{A}$ and by cinnabaramide $\mathrm{A}$ and its analogues.

\begin{tabular}{|lccr|} 
Compound & $\mathrm{C}-\mathrm{L}(\beta 1)$ & $\mathrm{IC}_{50}[\mathrm{nM}]^{[\mathrm{ad}]} \mathrm{T}-\mathrm{L}(\beta 2)$ & $\mathrm{CT}-\mathrm{L}(\beta 5)$ \\
\hline salinosporamide A & $32.7 \pm 14.7$ & $18.7 \pm 10.5$ & $3.1 \pm 4.8$ \\
cinnabaramide A & $248.6 \pm 8.4$ & $216.0 \pm 12.3$ & $11.9 \pm 7.4$ \\
17-chlorocinnabaramide A & $265.8 \pm 10.7$ & $442.5 \pm 6.8$ & $8.8 \pm 5.5$ \\
15-chlorocinnabaramide A & $402.9 \pm 10.5$ & $88.9 \pm 8.3$ & $9.3 \pm 5.9$ \\
cyclopentyl-cinnabaramide A & $301.2 \pm 7.8$ & $301.2 \pm 9.1$ & $64.9 \pm 5.3$
\end{tabular}

[a] $\mathrm{IC}_{50}$ values were obtained by linear regression of kinetics measurements and secondary hyperbolic regression.

tained from Roth, Germany. Oligonucleotides were purchased from Sigma. Standard methods for DNA isolation and manipulation were used. ${ }^{[36,37]}$ DNA fragments were isolated from agarose gels by use of the NucleoSpin Extract gel-extraction kit (Macherey-Nagel). Southern genomic library analysis was performed with the DIG DNA labeling and detection kit (Roche). Hybridization was carried out at $42^{\circ} \mathrm{C}$ for homologous probes with stringent washing at $68^{\circ} \mathrm{C}$. For heterologous probes, hybridization was performed at $42^{\circ} \mathrm{C}$ with stringent washing at $60^{\circ} \mathrm{C}$. PCR reactions were performed with Taq DNA polymerase (Fermentas) or Pfu polymerase
Table 3. Cytotoxicities of salinosporamide $A$ and of cinnabaramide $A$ and its analogues towards human tumor cell lines ${ }^{[a]}$ as evaluated by MTT assay ${ }^{[b]}$ or by PI staining ${ }^{[c]}$

\begin{tabular}{|c|c|c|c|}
\hline Compound & HCT-116 ${ }^{[\mathrm{b}]}$ & $\begin{array}{l}\text { RPMI-8226 } \\
\mathrm{IC}_{50}[\mu \mathrm{M}]^{[\mathrm{d}]}\end{array}$ & SW480 $0^{[b]}$ \\
\hline salinosporamide $\mathrm{A}$ & $0.047 \pm 0.003$ & $0.014 \pm 0.001$ & $0.013 \pm 2.3 \times 10^{5}$ \\
\hline cinnabaramide $\mathrm{A}$ & $5.906 \pm 0.301$ & $1.940 \pm 0.490$ & $0.931 \pm 0.141$ \\
\hline 17-chlorocinnabaramide A & $7.286 \pm 0.050$ & $0.841 \pm 0.190$ & $0.977 \pm 0.011$ \\
\hline 15-chlorocinnabaramide A & $2.376 \pm 0.433$ & $0.341 \pm 0.001$ & $0.457 \pm 0.007$ \\
\hline cyclopentylcinnabaramide A & $16.893 \pm 0.235$ & n.d. & n.d. \\
\hline
\end{tabular}

[a] HCT-116: colon carcinoma. RPMI-8226: myeloma. SW480: colon adenocarcinoma. [d] Values represent the average of two independent measurements. Incubation times: [c] $4 \mathrm{~d}$, or [b] $5 \mathrm{~d}$. The observed $\mathrm{IC}_{50}$ values were of the same order of magnitude as those previously reported. ${ }^{[10,33,35]}$ n.d.: not determined.

(Stratagene). Conditions for amplification with an Eppendorf Mastercycler were as follows: denaturation, $30 \mathrm{~s}$ at $95^{\circ} \mathrm{C}$; annealing, $30 \mathrm{~s}$ at $48-65^{\circ} \mathrm{C}$; extension, $45 \mathrm{~s}$ at $72^{\circ} \mathrm{C}$; 30 cycles and a final extension for $10 \mathrm{~min}$ at $72^{\circ} \mathrm{C}$. PCR products were purified by use of the High Pure PCR Product Purification kit (Boehringer Mannheim).

Construction of Streptomyces JS360 genomic cosmid library: Chromosomal DNA of the bacteria was prepared as described previously. ${ }^{[3]]}$ Partial digestion of the bacterial genome was performed with Sau3Al enzyme to provide fragments of about $35-40 \mathrm{kbp}$. The fragments were dephosphorylated and ligated into pOJ436 cosmid pretreated with Pvull, dephosphorylated, and restricted with BamHI. The ligation mixture was packaged with Gigapack III Gold (Stratagene) packaging extract and transduction of the resulting phages into E. coli HS966 created a genomic library of 2304 clones. For colony hybridization, the colonies were transferred twice onto a $22.2 \times 22.2 \mathrm{~cm}$ nylon membrane with a QPix (Hampshire, UK) colony picker. ${ }^{[38]}$

Screening of the cosmid library for the cinnabaramide gene cluster: From the chemical structures of the cinnabaramides we expected involvement of a PKS/NRPS gene cluster in biosynthesis of the compound. The bacterial cosmid library was therefore first screened for PKS genes by hybridization with a homologous ketosynthase (KS) probe generated from the bacterial genome under low-stringency conditions, with use of the degenerate oligonucleotides KS1UP and KSD1. ${ }^{[39]}$ Furthermore, an adenylation probe (NRPS) was generated from the bacterial genome with the aid of the degenerate primers NRPS-A1-up: (5'-CGG CTC CAC CGG CAC [ACGT]CC [ACGT]AA [AG]GG [ACGT]G-3') and NRPS-H1-dn: (5'-CGG CCG AGG TCG CC[ACGT] GT[ACGT] C[GT][AG] TA-3'), and used for hybridization of the cosmid library. Seven of the KS-positive cosmids were positively cross-hybridized with the NRPS probe and were subjected to PCR analysis for amplification of KS and NRPSadenylation fragments. The $P C R$ fragments were cloned into pCR2.1TOPO vector (Invitrogen) and sequenced. The PCR fragments generated from cosmid C:A17 showed significant homology to KS and adenylation-domain sequences from the salinosporamide gene cluster. After cosmid end-sequencing from the $\mathrm{T} 3$ and the T7 termini of the pOJ436, the cosmid was thus sequenced on both strands, by use of a shotgun library as described previously, ${ }_{1}^{[40]}$ and the sequence was introduced into the EMBL nucleotide database (accession number: FR687018).

Bioinformatics analysis: All sequence similarity searches were carried out at the amino acid level in the Gene Bank database with use of the BLAST program (release 2.0). Amino acid and nucleotide 
sequences were aligned with the aid of the Vector NTI advance 11 and Geneious 4.8.4 software packages (Invitrogen, USA, and Biomatters, New Zealand, respectively).

Inactivation in the cinnabaramide gene cluster: Inactivation of cinf, encoding octenoyl-CoA reductase/carboxylase (Ocr), and of cin $Q$, encoding a putative branched-chain amino acid aminotransferase, was performed by integration of the inactivation plasmids pCN1 and pCN2, respectively, into the Streptomyces JS360 genome. Internal fragments of the $\operatorname{cinF}(1044 \mathrm{bp})$ and $\operatorname{cinQ}(847 \mathrm{bp})$ with frame shift mutation in the $5^{\prime}$-end sequence were generated by PCR by use of the oligonucleotides Cinf-up (5'-ATG TAG CAG CTT GTC CCG AGC CGT A-3') and CinF-dn (5'-TTG TCG AAG GTG TGC AGG TAG-3'), and of CinQ-up (5'-CAG TGA CAG CGC GAC CCT CAT C-3') and CinQ-dn (5'-CAC GTC CCT GCC GGA GAG-3'; inserted nucleotides highlighted in bold). Next, the PCR products were cloned into the pCR2.1-TOPO vector (Invitrogen) for sequence analysis, and excised by use of the restriction enzymes EcoRV and HindllI. The resulting inserts were then subcloned into EcoRV and HindIII cloning sites of the conjugative plasmid pKC1132, ${ }^{[4]]}$ creating the inactivation plasmids $\mathrm{pCN} 1$ and $\mathrm{pCN} 2$. The plasmids were then introduced into E. coli $\mathrm{ET} 12567 / \mathrm{pUZ} 8002$. Appropriate transformants were then used for conjugation with JS360 spores as described previously. ${ }^{[22]}$ Plates containing putative exconjugants were overlaid with apramycin $\left(60 \mu \mathrm{g} \mathrm{mL}^{-1}\right)$ and nalidixic acid $\left(25 \mu \mathrm{g} \mathrm{mL}^{-1}\right)$. Because pKC1132 cannot replicate in Streptomyces, apramycinresistance strains could be produced only by homologous recombination between the conjugative plasmids and the genes in the JS360 genome. To confirm integration of the plasmid into the genome, and thus disruption of the genes, PCR analysis with the aid of the primer pTOPO-Hind (5'-GAG CTC GGA TCC ACT AGT-3') in combination with each of CinF-out (5'-ATC ATT TCA AGG TAC TTC-3'), CinQ-out ( $5^{\prime}$-CTC GGT GTA CAG CTC GCG-3'), and CinQ-out (5'-TTC TCA CGG AAG TCG ATC T-3') of the bacterial genome located upstream or downstream regions of the cloned fragments was performed. PCR fragments $1163 \mathrm{bp}$ and $980 \mathrm{bp}$ were only amplified from genome of the mutants JS360-cinF ${ }^{-}$and JS360-cinQ ${ }^{-}$.

Feeding experiments: JS360 was grown in YMG medium at $30^{\circ} \mathrm{C}$ for $24 \mathrm{~h}$ and was then transferred to Q6 medium $(25 \mathrm{~mL})$ supplemented variously with DL-3-cyclopentyl-alanine, deuterated cyclohexenyl-serine, 4-chlorooct-2-enoic acid, 4-chlorooct-2-enoyl-SNAC, 6-chlorooct-2-enoic acid, 6-chlorooct-2-enoyl-SNAC, 8-chlorooct-2enoic acid, 8-chlorooct-2-enoyl-SNAC, crotonic acid, pent-2-enoic acid, hex-2-enoic acid, or hept-2-enoic acid (all $0.1 \mathrm{~mm}$ ). These compounds were each added in three portions to the bacterial culture after 0,6 , and $12 \mathrm{~h}$, and further incubated for $24 \mathrm{~h}$. To investigate for production of cinnabaramides or their derivatives, culture supernatant $(20 \mathrm{~mL})$ was extracted three times with ethyl acetate $(20 \mathrm{~mL})$. After removal of the solvent in vacuo, the remainder was dissolved in methanol $(1 \mathrm{~mL})$ and $5 \mu \mathrm{L}$ of the solution was injected for HPLC-MS analysis.

\section{Synthesis of precursors for feeding experiments}

A) Synthesis of (E)-4-chlorooct-2-enoic acid: (E)-Oct-3-enoic acid (5 g, $35.2 \mathrm{mmol}$, Sigma-Aldrich) was added dropwise at RT under nitrogen to a solution of phenylselenium chloride $(3.4 \mathrm{~g}$, $17.6 \mathrm{mmol})$ in dry acetonitrile $(200 \mathrm{~mL})$. Molecular sieves $(4 \AA)$ were added, followed over $20 \mathrm{~h}$ by a solution of $\mathrm{N}$-chlorosuccinimide $(5.15 \mathrm{~g}, 38.5 \mathrm{mmol})$ in dry acetonitrile $(100 \mathrm{~mL})$. After addition, the mixture was stirred at RT for $2 \mathrm{~d}$. The solvent was removed under reduced pressure and the residue was diluted with diethyl ether $(100 \mathrm{~mL})$. The solid formed was removed by filtration and the filtrate was washed with water $(4 \times 25 \mathrm{~mL})$. The organic layer was dried over $\mathrm{MgSO}_{4}$ and the solvent was removed in vacuo. After purification by flash column chromatography over silica gel (with cyclohexane/ethyl acetate as mobile phase), the target compound $(1.6 \mathrm{~g})$ was obtained. Because NMR analysis indicated that the sample still contained oct-2-enoic acid (about $10 \%$ ) as a side product, the compound was further purified by distillation at $0.1 \mathrm{mbar} /$ $175^{\circ} \mathrm{C}$ to yield 4-chlorooct-2-enoic acid ( $93 \%$ purity by ${ }^{1} \mathrm{H}$ NMR, $1.3 \mathrm{~g}, 21 \%$, Figures S2 and S3).

B) Synthesis of (E)-6-chlorooct-2-enoic acid and its corresponding SNAC derivative

Methyl 4-chlorohexanoate: A solution of $\gamma$-ethylbutyrolactone ( $25 \mathrm{~g}$, $0.22 \mathrm{~mol})$ in dry $\mathrm{MeOH}(250 \mathrm{~mL})$ was saturated with $\mathrm{HCl}(\mathrm{g})$. The reaction mixture was stirred at RT in a sealed tube for $4 \mathrm{~d}$. Excess $\mathrm{HCl}$ was removed and the reaction mixture was concentrated to dryness. The crude product was diluted with water $(100 \mathrm{~mL})$ and extracted with $\mathrm{CH}_{2} \mathrm{Cl}_{2}(3 \times 75 \mathrm{~mL})$. The organic layer was washed with a saturated solution of $\mathrm{NaHCO}_{3}$, dried over $\mathrm{MgSO}_{4}$, and concentrated to dryness. The product was purified by distillation ( $\mathrm{bp}=72$ $74^{\circ} \mathrm{C}$ at $\left.11 \mathrm{mbar}\right)$ to yield $20.4 \mathrm{~g}(60 \%)$.

4-Chlorohexanal: A solution of DIBAL-H in $\mathrm{CH}_{2} \mathrm{Cl}_{2}(1 \mathrm{M}, 130 \mathrm{~mL})$ was added at $-78{ }^{\circ} \mathrm{C}$ to a solution of methyl 4-chlorohexanoate $(20.4 \mathrm{~g}$, $0.12 \mathrm{~mol})$ in dry $\mathrm{CH}_{2} \mathrm{Cl}_{2}(112 \mathrm{~mL})$. The reaction mixture was stirred at this temperature for $1 \mathrm{~h}$, after which it was poured into ice/ conc. $\mathrm{HCl}(140 \mathrm{~g} / 28 \mathrm{~mL})$. The aqueous layer was extracted with $\mathrm{CH}_{2} \mathrm{Cl}_{2}(2 \times 50 \mathrm{~mL})$. The combined organic layers were dried over $\mathrm{MgSO}_{4}$ and the solvent was removed under reduced pressure. The desired product $(17.8 \mathrm{~g})$ was obtained and used without further purification.

(E)-6-Chlorooct-2-enoic acid: A mixture of 4-chlorohexanal (17.8 g, $0.12 \mathrm{~mol})$ and malonic acid $(16.5 \mathrm{~g}, 0.16 \mathrm{~mol})$ in dry pyridine (37 mL) was stirred at $30^{\circ} \mathrm{C}$ for $4 \mathrm{~d}$, at $60^{\circ} \mathrm{C}$ for $1 \mathrm{~h}$, and finally at $95^{\circ} \mathrm{C}$ for $1 \mathrm{~h}$. The reaction mixture was poured into ice $/ 6 \mathrm{M} \mathrm{HCl}$ solution $(200 \mathrm{~mL})$ and extracted with $\mathrm{Et}_{2} \mathrm{O}(3 \times 100 \mathrm{~mL})$. The organic layer was extracted with $\mathrm{NaOH}$ solution $(3 \mathrm{M}, 2 \times 50 \mathrm{~mL})$. The aqueous layer was acidified with $\mathrm{HCl}(10 \%)$ to $\mathrm{pH} 2$ and then extracted with $\mathrm{Et}_{2} \mathrm{O}(3 \times 75 \mathrm{~mL})$. The new organic layer was dried over $\mathrm{MgSO}_{4}$ and the solvent was removed under reduced pressure to yield the desired compound ( $16.3 \mathrm{~g}$, $77 \%$ over two steps), which was used without further purification.

Corresponding NAC thioester: EDAC $(3.33 \mathrm{~g}, 17.4 \mathrm{mmol})$ was added to a solution of (E)-6-chlorooct-2-enoic acid $(2 \mathrm{~g}, 11.3 \mathrm{mmol})$ and $\mathrm{N}$ acetylcysteamine $(1.64 \mathrm{~g}, 13.7 \mathrm{mmol})$ in dry DMF $(115 \mathrm{~mL})$. The reaction mixture was stirred at RT overnight. $\mathrm{HCl}$ solution (10\%) was added $(50 \mathrm{~mL})$, and the mixture was diluted with water $(100 \mathrm{~mL})$ and extracted with $\mathrm{CH}_{2} \mathrm{Cl}_{2}(2 \times 150 \mathrm{~mL})$. The organic layer was washed with brine, dried over $\mathrm{MgSO}_{4}$, and concentrated to dryness. The product was purified by flash column chromatography (silica gel, cyclohexane/ethyl acetate) and preparative HPLC $\left(\mathrm{H}_{2} \mathrm{O} /\right.$ acetonitrile). The desired compound ( $295 \mathrm{mg}, 93 \%$ yield) was obtained (Figures S2 and S3).

C) Synthesis of $(E)$-8-chlorooct-2-enoic acid and its corresponding SNAC derivative

6-Chlorohexanal: A solution of sodium bichromate dihydrate ( $25 \mathrm{~g}$, $0.084 \mathrm{~mol})$ in water $(312 \mathrm{~mL})$ was added dropwise at reflux to a solution of 6-chlorohexanol $(25 \mathrm{~g}, 0.18 \mathrm{~mol})$ and $\mathrm{H}_{2} \mathrm{SO}_{4}(25 \mathrm{~mL})$ in water $(156 \mathrm{~mL})$, and at the same time the same amount of water was distilled off. More water was added $(30 \mathrm{~mL})$ and simultaneously distilled off from the reaction mixture. The distillate was extracted with $\mathrm{Et}_{2} \mathrm{O}(3 \times 100 \mathrm{~mL})$. The organic layer was dried over $\mathrm{MgSO}_{4}$ and concentrated to dryness. The product obtained (17.8 g) was a 
mixture of the starting alcohol and the desired corresponding aldehyde $(1: 1)$, and it was used without further purification for the next step.

(E)-8-Chlorooct-2-enoic acid: The mixture of 6-chlorohexanol and 6chlorohexanal $(1: 1,17.8 \mathrm{~g}$, about $7.9 \mathrm{~g} / 66 \mathrm{mmol}$ of the aldehyde), together with malonic acid $(8.25 \mathrm{~g}, 79.2 \mathrm{mmol})$ in dry pyridine $(18 \mathrm{~mL})$, was stirred at $30^{\circ} \mathrm{C}$ for $4 \mathrm{~d}$, at $60^{\circ} \mathrm{C}$ for $1 \mathrm{~h}$, and finally at $95^{\circ} \mathrm{C}$ for $1 \mathrm{~h}$. The reaction mixture was poured into ice $/ 6 \mathrm{M} \mathrm{HCl}$ solution $(100 \mathrm{~mL})$ and extracted with $\mathrm{Et}_{2} \mathrm{O}(3 \times 50 \mathrm{~mL})$. The organic layer was extracted with $\mathrm{NaOH}$ solution $(3 \mathrm{M}, 2 \times 25 \mathrm{~mL})$. The aqueous layer was acidified with $\mathrm{HCl}(10 \%)$ to $\mathrm{pH} 2$ and extracted with $\mathrm{Et}_{2} \mathrm{O}(3 \times 50 \mathrm{~mL})$. The new organic layer was dried over $\mathrm{MgSO}_{4}$ and the solvent was removed under reduced pressure to yield the desired compound $(10.8 \mathrm{~g})$, which was used without further purification.

Corresponding NAC thioester: EDAC $(3.12 \mathrm{~g}, 16.3 \mathrm{mmol})$ was added to a solution of $(E)-8$-chlorooct-2-enoic acid $(1.9 \mathrm{~g}, 10.8 \mathrm{mmol})$ and $\mathrm{N}$-acetylcysteamine $(1.64 \mathrm{~g}, 12.9 \mathrm{mmol})$ in dry DMF $(108 \mathrm{~mL})$. The reaction mixture was stirred at $\mathrm{RT}$ overnight. $\mathrm{HCl}$ solution $(10 \%$, $50 \mathrm{~mL}$ ) was added, and the mixture was diluted with water $(100 \mathrm{~mL})$ and extracted with $\mathrm{CH}_{2} \mathrm{Cl}_{2}(2 \times 150 \mathrm{~mL})$. The organic layer was washed with brine, dried over $\mathrm{MgSO}_{4}$, and concentrated to dryness. The product was purified by flash column chromatography (silica gel, cyclohexane/ethyl acetate) and afterward by preparative $\mathrm{HPLC}\left(\mathrm{H}_{2} \mathrm{O} /\right.$ acetonitrile). The desired compound $(460 \mathrm{mg}$, about $15 \%$ ) was obtained (Figures S2 and S3).

D) Investigation of the synthesis of $(E)-5$-chlorooct-2-enoic acid: Unfortunately, attempts to synthesize $(E)$-5-chlorooct-2-enoic acid by a strategy similar to that successfully applied for 6- and 8chlorooct-2-enoic acids failed. Spontaneous $\mathrm{HCl}$ elimination of the desired product, leading to the corresponding octa-2,4-dienoic acid is unavoidable.

Ethyl 3-chlorohexanoate: Benzotriazole $(29.5 \mathrm{~g})$ was added to a solution of $\mathrm{SOCl}_{2}(18.06 \mathrm{~mL})$ in dry $\mathrm{CH}_{2} \mathrm{Cl}_{2}(50 \mathrm{~mL})$. More $\mathrm{CH}_{2} \mathrm{Cl}_{2}$ was added until $165.4 \mathrm{~mL}$ of a $1.5 \mathrm{M}$ solution of $\mathrm{SOCl}_{2} /$ benzotriazole were obtained. This solution was added dropwise to a solution of ethyl 3-hydroxyhexanoate $(15.9 \mathrm{~g}, 99.2 \mathrm{mmol})$ in dry $\mathrm{CH}_{2} \mathrm{Cl}_{2}$ $(500 \mathrm{~mL})$, and the mixture was stirred at RT overnight. The solid formed was removed by filtration and the filtrate was washed with water $(2 \times 200 \mathrm{~mL})$, aq. $\mathrm{Na}_{2} \mathrm{CO}_{3}(10 \%, 150 \mathrm{~mL})$, and $\mathrm{NaHCO}_{3}$ $(150 \mathrm{~mL})$. The organic layer was dried over $\mathrm{MgSO}_{4}$ and concentrated to dryness. The product was purified by flash column chromatography (silica gel, cyclohexane/ethyl acetate) to give the target compound $(5.5 \mathrm{~g})$. Starting ethyl 3-hydroxyhexanoate $(10 \mathrm{~g})$ was recovered (yield $83 \%$, conversion $37 \%$ ).

3-Chlorohexanal: A solution of DIBAL-H in $\mathrm{CH}_{2} \mathrm{Cl}_{2}(1 \mathrm{M}, 33.8 \mathrm{~mL})$ was added at $-78^{\circ} \mathrm{C}$ to a solution of ethyl 3-chlorohexanoate $(5.5 \mathrm{~g}$, $30.8 \mathrm{mmol})$ in dry $\mathrm{CH}_{2} \mathrm{Cl}_{2}(28 \mathrm{~mL})$. The reaction mixture was stirred at this temperature for $1 \mathrm{~h}$, after which it was poured into $40 \mathrm{~g}$ ice/ $7.5 \mathrm{~mL}$ conc. $\mathrm{HCl}$ solution. The aqueous layer was extracted with $\mathrm{CH}_{2} \mathrm{Cl}_{2}(2 \times 20 \mathrm{~mL})$. The combined organic layer was dried over $\mathrm{MgSO}_{4}$ and the solvent was removed under reduced pressure. The desired product $(5 \mathrm{~g}$, theory: $100 \%=4.14 \mathrm{~g})$ was obtained and used without further purification.

(E)-5-Chlorooct-2-enoic acid/(2E,4E)-octa-2,4-dienoic acid: A mixture of 3-chlorohexanal $(4.1 \mathrm{~g}$, about $30 \mathrm{mmol})$ and malonic acid $(4.54 \mathrm{~g}, 43.4 \mathrm{mmol})$ in dry pyridine $(10 \mathrm{~mL})$ was stirred at $30^{\circ} \mathrm{C}$ for $4 \mathrm{~d}$, at $60^{\circ} \mathrm{C}$ for $1 \mathrm{~h}$, and finally at $95^{\circ} \mathrm{C}$ for $1 \mathrm{~h}$. The reaction mixture was poured into ice $/ 6 \mathrm{M} \mathrm{HCl}$ solution $(100 \mathrm{~mL})$ and extracted with $\mathrm{Et}_{2} \mathrm{O}(3 \times 25 \mathrm{~mL})$. The organic layer was extracted with $\mathrm{NaOH}$ solution $(3 \mathrm{M}, 2 \times 15 \mathrm{~mL})$. The aqueous layer was acidified with $\mathrm{HCl}$ $(10 \%)$ to $\mathrm{pH} 2$ and extracted with $\mathrm{Et}_{2} \mathrm{O}(3 \times 25 \mathrm{~mL})$. The new organic layer was dried over $\mathrm{MgSO}_{4}$ and the solvent was removed under reduced pressure. The crude reaction product was purified by flash column chromatography (silica gel, cyclohexane/ethyl acetate) to yield (2E,4E)-octa-2,4-dienoic acid as reaction product. Any attempts to avoid $\mathrm{HCl}$ elimination and to obtain the desired $(E)-5$ chlorooct-2-enoic acid failed (Figures S2 and S3).

Analytical methods and structure elucidation: HPLC-MS was performed with a HPLC-DAD system (Agilent 1100) coupled to an HCT ultra ESI-MS ion trap apparatus (Bruker Daltonics) operating in positive ionization mode. Separation was achieved by use of a Luna RP-C18 column with a solvent system consisting of a water to acetonitrile gradient. For separation of cinnabaramides and their derivatives and of oct-2-enoyl-SNAC and 2-carboxyl-octenoyl-SNAC esters, a solvent system based on water (A)/acetonitrile (B) containing formic acid (0.1\%) was used. Gradient: $0-2$ min $5 \% \mathrm{~B} ; 2-$ 22 min linear from $5 \%$ to $95 \% \mathrm{~B} ; 22-25 \mathrm{~min}$ isocratic at $95 \% \mathrm{~B}$; 25-27 min linear from $95-5 \% \mathrm{~B}$.

High-resolution measurements were performed with an Accela UPLC-system (Thermo-Fisher) coupled to an LTQ-Orbitrap (linear trap-FT-Orbitrap combination) operating in positive ionization mode with a Waters BEH-C18 column with a solvent system consisting of a water (A)/acetonitrile (B) gradient containing formic acid $(0.1 \%)$.

NMR spectra were recorded in $\left[D_{6}\right]$ DMSO with a Bruker DRX 500 spectrometer at $303 \mathrm{~K}$, operating at $500.13 \mathrm{MHz}$ proton frequency. The solvent peak was used as internal reference $\left(\delta_{\mathrm{H}}=2.50 \mathrm{ppm}\right.$, $\delta_{\mathrm{C}}=39.5 \mathrm{ppm}$ ). Chemical shifts are given in ppm, coupling constants in Hertz. In the cases of the synthetic precursors used for the mutasynthesis projects, NMR spectra were obtained with a Bruker AVANCE spectrometer at $293 \mathrm{~K}$ in $\mathrm{CDCl}_{3}(300 \mathrm{MHz}$ proton frequency), which was also used as internal reference ( $\delta_{H}=$ 7.26 ppm). Analytical HPLC-MS was performed with an Agilent 1100 HPLC system coupled with an Agilent DAD detector, an evaporating light scattering detector (ELSD), and an LCT mass spectrometer (Micromass, Manchester, UK) operating in positive and negative ESI modes. A Waters Symmetry C18 column $(3.5 \mu \mathrm{m}, 150 \times 2.1 \mathrm{~mm})$ and a linear gradient from 0 to $100 \% \mathrm{MeCN}(0.1 \% \mathrm{HCOOH}$, flow rate $0.4 \mathrm{~mL} \mathrm{~min}^{-1}$ ) in $21 \mathrm{~min}$ were used. HR-ESIMS data were obtained with a Bruker MicroTOF instrument, coupled with an HPLC system as described above and with use of sodium formate as internal reference. Optical rotation values were measured in $\mathrm{MeOH}$ with a Schmidt + Haensch Polartronic HH8 polarimeter; concentrations are given in $\mathrm{g}$ per $100 \mathrm{~mL}$. Structure elucidation of the novel cinnabaramide derivatives was achieved by thorough interpretation of 1D and 2D NMR spectra, combined with LC-MS data including extracted UV as well as positive and negative mode ESI spectra. Cinnabaramide A was used for comparison. Additionally, the molecular formulas and elemental compositions of all cinnabaramide derivatives were confirmed by high-resolution ESI-MS. The NMR dataset used consisted of 1D proton and carbon, ${ }^{1} \mathrm{H},{ }^{1} \mathrm{H}$ gCOSY, ${ }^{1} \mathrm{H},{ }^{13} \mathrm{C}$ gHSQC, and ${ }^{1} \mathrm{H},{ }^{13} \mathrm{C}$ gHMBC spectra (Figures $\mathrm{S} 3$ and $\mathrm{S} 4$ ).

Inhibition assay with human $20 \mathrm{~S}$ proteasome: All chemicals were of reagent grade and buffers were made with deionized distilled water. Inhibition experiments were performed in HEPES buffer ( $25 \mathrm{~mm}, \mathrm{pH} 7.5)$ containing EDTA $(0.5 \mathrm{~mm})$, Triton-X100 $(0.05 \%, \mathrm{v} /$ $v)$, and SDS $(0.001 \%, w / v)$. Inhibition was monitored by measuring the release of AMC-coupled substrate peptides for the C-L, CT-L, and T-L activities, respectively. Compounds were pre-incubated for $15 \mathrm{~min}$ at $37^{\circ} \mathrm{C}$ in serial dilutions from 0.03 to $3000 \mathrm{~nm}$ with 
human $20 \mathrm{~S}$ proteasome $(2 \mathrm{nM}$, Biomol) dissolved either in buffer $\mathrm{A}$ (HEPES (pH 8.0, $20 \mathrm{~mm})$, EDTA $(0.5 \mathrm{~mm})$, SDS $(0.035 \%, w / v))$ for CT-L and C-L activities or in buffer B (HEPES (pH 8.0, $20 \mathrm{~mm}$ ), EDTA (0.5 mM)) for T-L activity. Boc-LRR-AMC.2 HCl, suc-LLVY-AMC, and ZLLE-AMC (Bachem) were made up to $50 \mathrm{~mm}$ DMSO stocks in order to monitor T-L, CT-L, and C-L activities, respectively. Reactions were initiated by addition of AMC substrates to final concentrations of $2 \mu \mathrm{M}$. The emission at $460 \mathrm{~nm}$ ( $5 \mathrm{~nm}$ cutoff; excitation at $380 \mathrm{~nm}$ ) was measured with a Spectramax M5 fluorescence reader (Molecular Devices) in black 96-well plates (BD Falcon) at $37^{\circ} \mathrm{C}$ over $90 \mathrm{~min}$. The measured AMC production was in the linear range of an AMC standard curve.

MTT assay: Cells were seeded at $6 \times 10^{3}$ cells per well on 96-well plates (Corning CellBind ${ }^{\circledR}$ ) in complete medium $(180 \mu \mathrm{L})$ and directly treated with compounds dissolved in methanol in a serial dilution. After $5 \mathrm{~d}$ incubation, MTT [3-(4,5-dimethyl-2-thiazolyl)-2,5diphenyl tetrazolium bromide, $20 \mu \mathrm{L}$ of $5 \mathrm{mg} \mathrm{mL}^{-1}$ stock] in PBS (phosphate-buffered saline, $\mathrm{pH}$ 7.4) was added to each well and further incubation at $37^{\circ} \mathrm{C}$ was carried out for $2 \mathrm{~h}$. The medium was then discarded and cells were washed with PBS before addition of propan-2-ol/10 $\mathrm{N} \mathrm{HCl}(250: 1,100 \mu \mathrm{L})$ in order to dissolve formazan granules. The absorbance at $570 \mathrm{~nm}$ was measured with a microplate reader (EL808, Bio-Tek Instruments, Inc.), and cell viability was expressed as percentage relative to the corresponding methanol control. $I_{50}$ values were obtained by sigmoidal curve fitting.

Cytotoxicity assay (propidium iodide staining): Cells were harvested from exponential phase cultures, counted, and plated in 96well microtiter plates at cell densities of 10000 to 80000 for hematological cancer cell lines. After a $24 \mathrm{~h}$ recovery period to allow cells to resume exponential growth, culture medium (four control wells/plate) or culture medium with the test compound $(10 \mu \mathrm{L})$ was added with use of a liquid handling robotic system and treatment was continued for $4 \mathrm{~d}$. Compounds were applied in half-log increments at ten concentrations in duplicate. For hematological cancer cell lines (growing in suspension), $30 \mathrm{~min}$ after addition of PI (propidium iodide, $7 \mu \mathrm{g} \mathrm{m}^{-1}$ ), fluorescence (FU1) was measured to quantify dead cells. Triton X-100 $(0.1 \%, v / v)$ was added next, resulting in permeability of all cells (viable + dead cells). After a second fluorescence measurement (FU2), the amount of viable cells was calculated by subtraction of FU1 from FU2. Growth inhibition/cytotoxicity is expressed as Test/Control $\times 100(\% \mathrm{~T} / \mathrm{C}) . \quad \mathrm{IC}_{50}$ values were calculated by nonlinear regression (log [inhibitor] vs response (\% T/C)) with the aid of the analysis software GraphPad Prism, Prism 5 for Windows, version 5.01 (GraphPad Software, Inc.). For calculation of mean $\mathrm{IC}_{50}$ values the geometric means were used.

Determination of antifungal activities: Minimal inhibitory concentrations (MICs) in the serial dilution assay were determined in 96well microtiter plates in a manner similar to that described previously, ${ }_{1}^{[43]}$ with use of Botrytis cinerea (DSM 5144), Pyricularia oryzae (DSM 62938), and Mucor plumbeus (MUCL 49355) as test organisms. Spore suspensions of the fungi were prepared from wellgrown YMG (glucose $0.4 \%$, malt extract $1 \%$, yeast extract $0.4 \%$, $\mathrm{pH}$ 6.3) agar plates and the initial titer for the biological assay was adjusted to initial titers of 105 spores per $\mathrm{mL}$ YMG medium.

The chlorinated cinnabaramides arising from the precursor feeding experiments and the cyclopentyl analogue of cinnabaramide $A$ were tested for comparison with cinnabaramide $A$, salinosporamide $A$, and actinomycin $C$ complex. All test compounds were dissolved in methanol and supplied to the microtiter plates in serial dilutions $\left(100,50,25,12.5,6.3,3.1,1.6\right.$, and $\left.0.8 \mu \mathrm{gmL}^{-1}\right)$. The MICs were determined after $24 \mathrm{~h}$ of incubation by OD measurement.

\section{Acknowledgements}

Research in R.M.'s laboratory was funded by the Bundesministerium für Bildung und Forschung (BMBF, FKZ: 0315385A). We gratefully acknowledge expert technical assistance by Andrea Rademacher and Dirk Müller (InterMed Discovery GmbH). Furthermore, we thank Oncotest (Freiburg, Germany) for determination of the cytotoxic activities against multiple myeloma cells.

Keywords: biosynthesis - mutasynthesis - natural products precursor-directed biosynthesis $\cdot$ proteasome inhibitors

[1] D. J. Newman, G. M. Cragg, K. M. Snader, J. Nat. Prod. 2003, 66, 1022 1037.

[2] D. J. Newman, G. M. Cragg, J. Nat. Prod. 2007, 70, 461-477.

[3] J. Berdy, J. Antibiot. 2005, 58, 1-26.

[4] R. H. Baltz, Nat. Biotechnol. 2006, 24, 1533-1540.

[5] K. J. Weissman, P. F. Leadlay, Nat. Rev. Microbiol. 2005, 3, 925-936.

[6] K. J. Weissman, R. Müller, ChemBioChem 2008, 9, 826-848.

[7] C. T. Walsh, Acc. Chem. Res. 2007, 40, 4-10.

[8] S. A. Samel, M. A. Marahiel, L. O. Essen, Mol. BioSyst. 2008, 4, 387-393.

[9] M. Stadler, J. Bitzer, A. Mayer-Bartschmid, H. Müller, J. Buchholz, F. Gantner, H. V. Tichy, P. Reinemer, K. B. Bacon, J. Nat. Prod. 2007, 70, 246-252.

[10] R. H. Feling, G. O. Buchanan, T. J. Mincer, C. A. Kauffman, P. R. Jensen, W. Fenical, Angew. Chem. 2003, 115, 369-371; Angew. Chem. Int. Ed. 2003, 42, 355-357.

[11] L. L. Beer, B. S. Moore, Org. Lett. 2007, 9, 845-848.

[12] R. P. McGlinchey, M. Nett, A. S. Eustaquio, R. N. Asolkar, W. Fenical, B. S. Moore, J. Am. Chem. Soc. 2008, 130, $7822-7823$.

[13] A. S. Eustaquio, S. J. Nam, K. Penn, A. Lechner, M. C. Wilson, W. Fenical, P. R. Jensen, B. S. Moore, ChemBioChem 2010.

[14] J. Adams, Cancer Cell 2004, 5, 417-421.

[15] B. S. Moore, A. S. Eustaquio, R. P. McGlinchey, Curr. Opin. Chem. Biol. 2008, 12, 434-440.

[16] T. A. M. Gulder, B. S. Moore, Angew. Chem. Int. Ed. 2010, 49, 9346-9367.

[17] M. Groll, R. Huber, B. C. Potts, J. Am. Chem. Soc. 2006, 128, 5136-5141.

[18] A. S. Eustaquio, R. P. McGlinchey, Y. Liu, C. Hazzard, L. L. Beer, G. Florova, M. M. Alhamadsheh, A. Lechner, A. J. Kale, Y. Kobayashi, K. A. Reynolds, B. S. Moore, Proc. Natl. Acad. Sci. USA 2009, 106, 12295-12300.

[19] M. A. Fischbach, C. T. Walsh, Chem. Rev. 2006, 106, 3468-3496.

[20] G. Yadav, R. S. Gokhale, D. Mohanty, J. Mol. Biol. 2003, 328, 335-363.

[21] K. Buntin, H. Irschik, K. J. Weissman, E. Luxenburger, H. Blöcker, R. Müller, Chem. Biol. 2010, 17, 342-356.

[22] H. Irschik, H. Reichenbach, G. Höfle, R. Jansen, J. Antibiot. 2007, 60, $733-738$

[23] H. Steinmetz, H. Irschik, B. Kunze, H. Reichenbach, G. Höfle, R. Jansen, Chem. Eur. J. 2007, 13, 5822-5832.

[24] D. W. Udwary, L. Zeigler, R. N. Asolkar, V. Singan, A. Lapidus, W. Fenical, P. R. Jensen, B. S. Moore, Proc. Natl. Acad. Sci. USA 2007, 104, $10376-$ 10381.

[25] G. L. Challis, J. Ravel, FEMS Microbiol. Lett. 2000, 187, 111-114.

[26] M. A. Marahiel, T. Stachelhaus, H. D. Mootz, Chem. Rev. 1997, 97, 2651 2674.

[27] S. Mahlstedt, E. N. Fielding, B. S. Moore, C. T. Walsh, Biochemistry 2010, 49, $9021-9023$

[28] M. Nett, B. S. Moore, Pure Appl. Chem. 2009, 81, 1075-1084.

[29] M. Nett, T. A. Gulder, A. J. Kale, C. C. Hughes, B. S. Moore, J. Med. Chem. 2009, 52, 6163-6167.

[30] T. J. Erb, I. A. Berg, V. Brecht, M. Muller, G. Fuchs, B. E. Alber, Proc. Natl. Acad. Sci. USA 2007, 104, $10631-10636$.

[31] Y. Liu, C. Hazzard, A. S. Eustaquio, K. A. Reynolds, B. S. Moore, J. Am. Chem. Soc. 2009, 131, 10376-10377. 
[32] W. Fenical, P. R. Jensen, M. A. Palladino, K. S. Lam, G. K. Lloyd, B. C. Potts, Bioorg. Med. Chem. 2009, 17, 2175-2180.

[33] A. S. Eustaquio, B. S. Moore, Angew. Chem. 2008, 120, 4000-4002 Angew. Chem. Int. Ed. 2008, 47, 3936-3938.

[34] R. R. Manam, K. A. McArthur, T. H. Chao, J. Weiss, J. A. Ali, V. J. Palombella, M. Groll, G. K. Lloyd, M. A. Palladino, S. T. Neuteboom, V. R. Macherla B. C. Potts, J. Med. Chem. 2008, 51, 6711-6724.

[35] K. A. Reed, R. R. Manam, S. S. Mitchell, J. Xu, S. Teisan, T.-H. Chao, G. Deyanat-Yazdi, S. T. Neuteboom, K. S. Lam, B. C. M. Potts, J. Nat. Prod. 2007, 70, 269-276.

[36] J. Sambrook, D.W. Russell, Molecular Cloning: A Laboratory Manual, Cold Spring Harbor Laboratory Press, Cold Spring Harbor, NY 2001.

[37] T. Kieser, M. Bibb, M. J. Buttner, K. F. Chater, D. A. Hopwood, Practical Streptomyces Genetics, The John Innes Foundation, Norwich, 2000, pp. 613.
[38] I. Dunham in Genome Analysis: A Laboratory Manual: Cloning System (Ed.: B. Birren), Cold Spring Harbor Laboratory Press, New York 1997, pp. $1-86$.

[39] S. Beyer, B. Kunze, B. Silakowski, R. Müller, Biochim. Biophys. Acta Gene Struct. Expression 1999, 1445, 185-195.

[40] B. Silakowski, H. U. Schairer, H. Ehret, B. Kunze, S. Weinig, G. Nordsiek, P. Brandt, H. Blöcker, G. Höfle, S. Beyer, R. Müller, J. Biol. Chem. 1999, 274 $37391-37399$.

[41] M. Bierman, R. Logan, K. Brien, E. T. Sena, R. N. Rao, B. E. Schoner, Gene $1992,116,43-49$

[42] S. Hoyt, G. H. Jones, J. Bacteriol. 1999, 181, 3824-3829.

[43] M. Stadler, D. N. Quang, A. Tomita, T. Hashimoto, Y. Asakawa, Mycol. Res. 2006, $110,811-820$

Received: January 14, 2011

Published online on March 8, 2011 